\title{
METODODLOGIA ARCHEOLOGII/PRAHISTORII PROFESORA DR. HAB. JANA ŻAKA (1923-1990) PO 30 LATACH. MIĘDZY MODERNISTYCZNYMI DĄŻENIAMI A POSTMODERNISTYCZNĄ RZECZYWISTOŚCIĄ
}

\author{
METHODOLOGY OF ARCHEOLOGY / PREHISTORY \\ OF PROFESSOR JAN ŻAK (1923-1990) AFTER 30 YEARS. \\ BETWEEN MODERNIST DESIGN \\ AND POSTMODERNIST REALITY
}

\author{
Danuta Minta-Tworzowska \\ https://orcid.org/0000-0003-3330-6025 \\ Wydział Archeologii Uniwersytetu im. Adama Mickiewicza \\ ul. Uniwersytetu Poznańskiego 7, 61-614 Poznań \\ danminta@amu.edu.pl
}

\begin{abstract}
January 4, 2020 was the 30th anniversary of the death of Professor Jan Żak, who died prematurely at the age of 67 . His work and scientific activities were known and appreciated in various countries and during difficult times when he was professionally involved in archeology. The biography of Professor Jan Żak resulted largely from the spirit of the times in which he lived, but also from his open, curious personality. He touched the warfare, and his professional life took place in the realities of the People's Republic of Poland; he also witnessed its dramatic end. The aim of this article is not only to recall the methodological and theoretical foundations of J. Żak's scientific work, but also to try to answer the question about the contemporary methodology of archeology, practiced by the Professor's students and subsequent generations.
\end{abstract}

KEY WORDS: methodology and theory of archeology at the University of Adam Mickiewicz in Poznań, modernism and postmodernism in archeology, the methodology of Jan Żak 


\section{PODSTAWOWE FAKTY Z ŻYCIA PROF. DR. HAB. JANA ŻAKA}

Wszelkie osiągnięcia naukowe, dydaktyczne i organizacyjne Profesora Jana Żaka oraz zasługi sytuują go w gronie najwybitniejszych polskich archeologów, w tym luminarzy Uniwersytetu im. Adama Mickiewicza w Poznaniu (Minta-Tworzowska, 1991, 2001a, 2001b, 2019; Minta-Tworzowska, Rączkowski, 2001a, 2001b).

We wspomnieniu o Profesorze Janie Żaku spróbujmy uporządkować pewne fakty. Urodził się 22 marca 1923 r. w Betkowie koło Kościana w Wielkopolsce, w rodzinie inteligenckiej. Jego matką była Salomea ze Śmierzchalskich, natomiast ojciec Walenty Żak był administratorem dóbr ziemskich w Betkowie. Jan Żak, po ukończeniu sześciu klas szkoły powszechnej im. S. Konarskiego w Poznaniu, uczęszczał do gimnazjum im. Marii Magdaleny w Poznaniu. Tzw. małą maturę uzyskał w nim w czerwcu 1939 r., a więc tuż przed wybuchem II wojny światowej. Podczas wojny, 8 grudnia 1939 r., został razem z rodziną przesiedlony przez Niemców do Generalnej Guberni, do Starego Zamościa. Pracował tam początkowo jako robotnik w cukrowni Klemensów (w latach 1940-1941), a potem (w latach 1941-1942) jako asystent rolniczy w Majdanie Stuleńskim oraz w Stulnie gm. Uhrusk (koło Chełma Lubelskiego). W tym czasie krótko uczestniczył w działaniach prowadzonych przez Bataliony Chłopskie. Jednak już wkrótce, 20 stycznia 1943 r., został wcielony do przymusowej organizacji pracy Baudienst w Chełmie Lubelskim, skąd uciekł i ukrywał się początkowo koło Krasnegostawu, a potem u rodziny koło Grójca. W czasie łapanki (22 czerwca 1943 r.) został zatrzymany i Sonderdienst wysłało Go do Austrii na ,roboty przymusowe". Droga do tej przymusowej pracy wiodła od Strasshof-Wagram (2 tygodnie) do Innsbrucku. Tam przez miesiąc pracował jako robotnik rolny, a następnie został konduktorem kolejki linowej Hungerburg-Hafellekar. Przebywał w Insbruku do końca 1944 r. Dzięki pomocy austriackiego ruchu oporu dostał się do Włoch w rejon Merano. Przybył tam w mundurze żołnierza włoskiego wraz z transportem ciężko rannych żołnierzy włoskich wracających z frontu wschodniego. Znalazłszy się w północnych Włoszech Jan Żak wstąpił do antyfaszystowskiej grupy partyzanckiej, a następnie na początku 1945 r. przekroczył Apeniny i zaciągnął się do I Brygady III Dywizji Strzelców Karpackich, biorąc udział we wszystkich jej późniejszych działaniach wojennych. Po wojnie odkomenderowano go do szkoły podchorążych piechoty w Materze koło Bari, którą ukończył po 9 miesiącach.

Następnie uczęszczał na kursy licealne w Matino koło Taranto, jednak już w sierpniu 1946 r. wyjechał wraz z całą szkołą podchorążych do Anglii, do Yorkshire. Tam czekał do stycznia 1947 r. na powrót do Polski, który bez wahania zadeklarował i wykazał się wielką determinacją w tym zakresie, mimo że wielu jego kolegów zostało w Anglii. Jak często wspominał, w czekaniu na powrót do Polski najgorsza była bezczynność, którą źle znosił. Wrócił do Poznania 7 stycznia 1947 r. i podjął naukę w Liceum im. Marii Magdaleny, uzyskując maturę 22 czerwca 1948 r. (z wynikiem bardzo dobrym). W tym czasie udzielał się w takich organizacjach, jak Związek Młodzieży Demokratycznej, którego był przewodniczącym czy KW Związku Młodzieży Demokratycznej Poznań. 


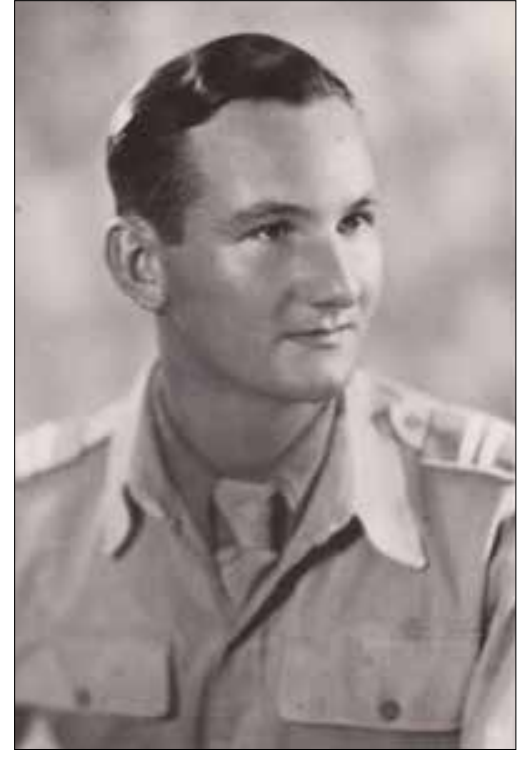

Ryc. 1. Jan Żak w mundurze podchorążego (archiwum prywatne)

Fig. 1. Jan Żak in a cadet uniform (private collection)

Zły stan zdrowia (choroba płuc) uniemożliwił mu podjęcie studiów uniwersyteckich bezpośrednio po ukończeniu szkoły średniej. Ostatecznie podjął je na Uniwersytecie Poznańskim pod koniec roku akademickiego 1948/1949 na kierunku prehistoria u prof. dr. Józefa Kostrzewskiego i częściowo u prof. dr. Witolda Hensla. Miał wówczas 25 lat i z ogromnym zapałem nadrabiał czas zabrany mu przez wojnę. Studiował u znanych autorytetów i tak etnografię u prof. Eugeniusza Frankowskiego i prof. Józefa Gajka, antropologię u prof. Jana Czekanowskiego, historię średniowiecza u prof. Kazimierza Tymienieckiego oraz filologię słowiańską u prof. Władysława Kuraszkiewicza. Opanował materiał z zakresu archeologii klasycznej, studiując ją u prof. Mieczysławy Ruxerówny, ale nie weszła ona w zakres Jego magisterium. J. Żak opowiadał, że prof. Ruxerówna wyznaczyła mu termin egzaminu w trakcie procesji Bożego Ciała. Mimo że procesja trwała bardzo długo, to egzamin nie zakończył się, a pani Profesor uznała, że muszą się spotkać raz jeszcze. Jednak ówczesny student J. Żak nie podjął już tego wyzwania i wybrał inną specjalność. Magisterium z filozofii w zakresie prehistorii, etnografii i antropologii uzyskał w czerwcu 1952 r. na podstawie pracy Kształtowanie się ośrodka feudalnego na Ostrowie Tumskim w Poznaniu (ocenionej na bardzo dobry przez prof. E. Frankowskiego i prof. W. Hensla). Jeszcze w trakcie studiów, 1 maja 1950 r., Profesor podjął pracę jako asystent, a później starszy asystent w Kierownictwie Badań nad Początkami Państwa Polskiego i prowadził prace wykopaliskowe w Poznaniu. To on pierwszy nakreślił prawdopodobny wizerunek piastowskiego zespołu pałacowo-sakralnego na Ostrowie Tumskim, powielany w swym ogólnym założeniu do dzisiaj. W tej placówce naukowej 18 stycznia $1960 \mathrm{r}$. uzyskał doktorat $\mathrm{w}$ zakresie nauk humanistycznych na podstawie pracy Kontakty społeczeństw zachodniosłowiańskich ze skandynawskimi od VI do VIII wieku. Praca 
została napisana pod kierunkiem prof. W. Hensla, a recenzowana była przez prof. Józefa Kostrzewskiego i prof. Kazimierza Tymienieckiego. Kariera naukowa zaczęła rozwijać się błyskawiczne, tym bardziej że wszelkie podwoje nauki otwierał mu fakt bycia uczniem Witolda Hensla, wschodzącej wielkiej postaci polskiej archeologii. Oprócz tego wiodło mu się w życiu osobistym - ożenił się, a w 1953 r. urodził mu się syn Marek.

Następny etap szybkiej i błyskotliwej kariery naukowej Jana Żaka rozpoczął się wraz z jego przejściem od 1 października 1961 r. z IHKM PAN do pracy w Katedrze Archeologii Polski i Powszechnej UAM (obecnie Wydział Archeologii) w charakterze adiunkta. Natomiast habilitował się 15 maja 1964 r., a więc w cztery lata po doktoracie, na podstawie trzytomowej pracy o niezwykle doniosłym znaczeniu naukowym Importy skandynawskie na ziemiach zachodniosłowiańskich od IX do XI wieku (Żak, 1963). Praca ta stanowiła próbę wszechstronnego rozwiązania zagadnienia kontaktów dwóch światów, poczynając od VI w., a na XI w. kończąc. Był to wielki sukces, ale cena zdrowotnie bardzo wysoka - po raz drugi zachorował na płuca. I tym razem zwalczył śmiertelną chorobę. Dalsza droga zawodowa Profesora to uzyskanie 30 stycznia 1965 r. stanowiska docenta w Katedrze Archeologii. Drukowana praca o „Importach” skandynawskich oraz maszynopis kolejnej pracy Wczesnofeudalna Skandynawia (Żak, 1969) były podstawą mianowania go z dniem 28 grudnia $1968 \mathrm{r}$. na stanowisko profesora nadzwyczajnego. 1 września 1969 r. Profesor Jan Żak został powołany na stanowisko kierownika ówczesnej Katedry Archeologii i piastował je jako dyrektor Instytutu Prahistorii (po zmianie nazwy katedry od 1982 r.) do końca swojego życia (z roczną przerwą związaną z urlopem zdrowotnym). W 1976 r. otrzymał tytuł profesora zwyczajnego. Przez wiele lat był jedynym w Poznaniu profesorem tytularnym archeologii.

Z tego pobieżnego przedstawienia dokonań Profesora Jana Żaka rodzi się niedowierzanie, że jeden człowiek mógł tyle dokonać. Podobne odczucia towarzyszą, gdy przyjrzymy się Jego ogromnemu trudowi, jaki podjął na polu organizacji nauki, zarówno uniwersyteckiej, jak i pozauniwersyteckiej. W ramach swojej pracy na Uniwersytecie im. Adama Mickiewicza pełnił funkcję najpierw kierownika Katedry Archeologii Pradziejowej i Wczesnośredniowiecznej, a następnie (od 1982 r.), po jej przekształceniu w Instytut Prahistorii - funkcję dyrektora; był również kierownikiem Zakładu Prahistorii Powszechnej (do 1987 r.), natomiast Zakładem Historii i Metodologii Prahistorii (jedyną tego typu jednostką uniwersytecką w Polsce) kierował do końca życia.

Dzięki staraniom Profesora Instytut Prahistorii UAM zyskał w 1984 r. własne czasopismo Folia Praehistorica Posnaniensia (t. 1, 1985), którego był pierwszym redaktorem. Był też członkiem komitetów redakcyjnych Slavia Antiqua, Fontes Archaeologici Posnanienses i Pomorania Antiqua.

Miarą zasług są honorowe prestiżowe funkcje i wyróżnienia. Profesor Jan Żak reprezentował Polskę jako członek Międzynarodowej Unii Nauk Pra- i Protohistorycznych przy UNESCO, należąc również do Rady Stałej tej Unii. Należał do wielu stowarzyszeń naukowych, był członkiem korespondentem Niemieckiego Instytutu 
Ryc. 2. Prof. Jan Żak na zdjęciu portretowym z 1976 r. (fot. Franciszek Lachowicz)

Fig. 2. Prof. Jan Żak in a portrait photo from 1976 (photo by Franciszek Lachowicz)

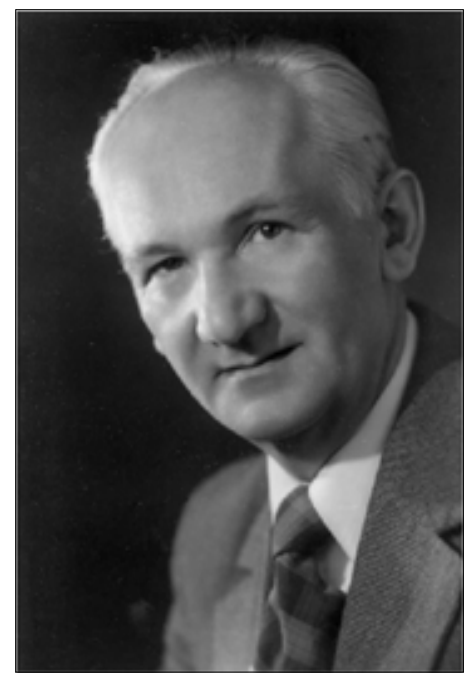

Archeologicznego (RFN), byłym członkiem Komitetu Nauk Etnologicznych PAN, członkiem Komitetu Słowianoznawstwa PAN, przewodniczącym Komisji Archeologicznej Poznańskiego Towarzystwa Przyjaciół Nauk, przewodniczącym Rady Naukowej Archeologicznej Ministerstwa Kultury i Sztuki. Przez wiele lat był przewodniczącym Rady Naukowej Muzeum Archeologicznego w Poznaniu i członkiem tej Rady oraz Rady Naukowej Muzeum w Zielonej Górze, Koszalinie i na Lednicy. Pełnił także funkcję wiceprzewodniczącego poznańskiego oddziału Towarzystwa Archeologicznego i Numizmatycznego. Powołano go również na członka Centralnej Komisji Kwalifikacyjnej przy Ministerstwie Nauki, Szkolnictwa Wyższego i Techniki.

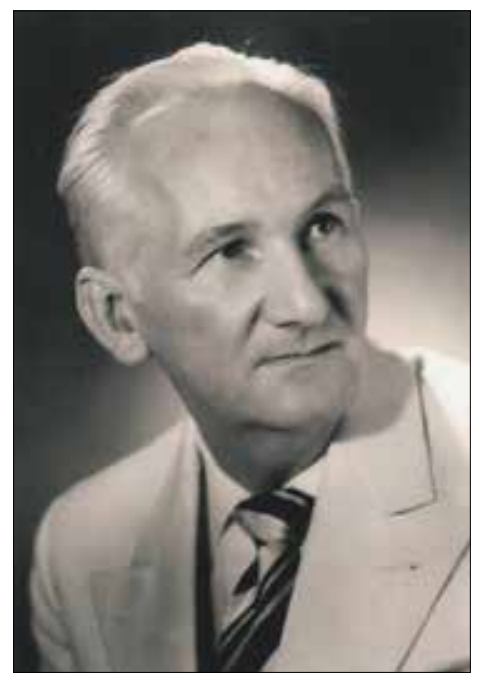

Ryc. 3. Prof. Jan Żak na zdjęciu portretowym z 1982 r. (fot. F. Lachowicz)

Fig. 3. Prof. Jan Żak in a portrait photo from 1982 (photo by F. Lachowicz) 


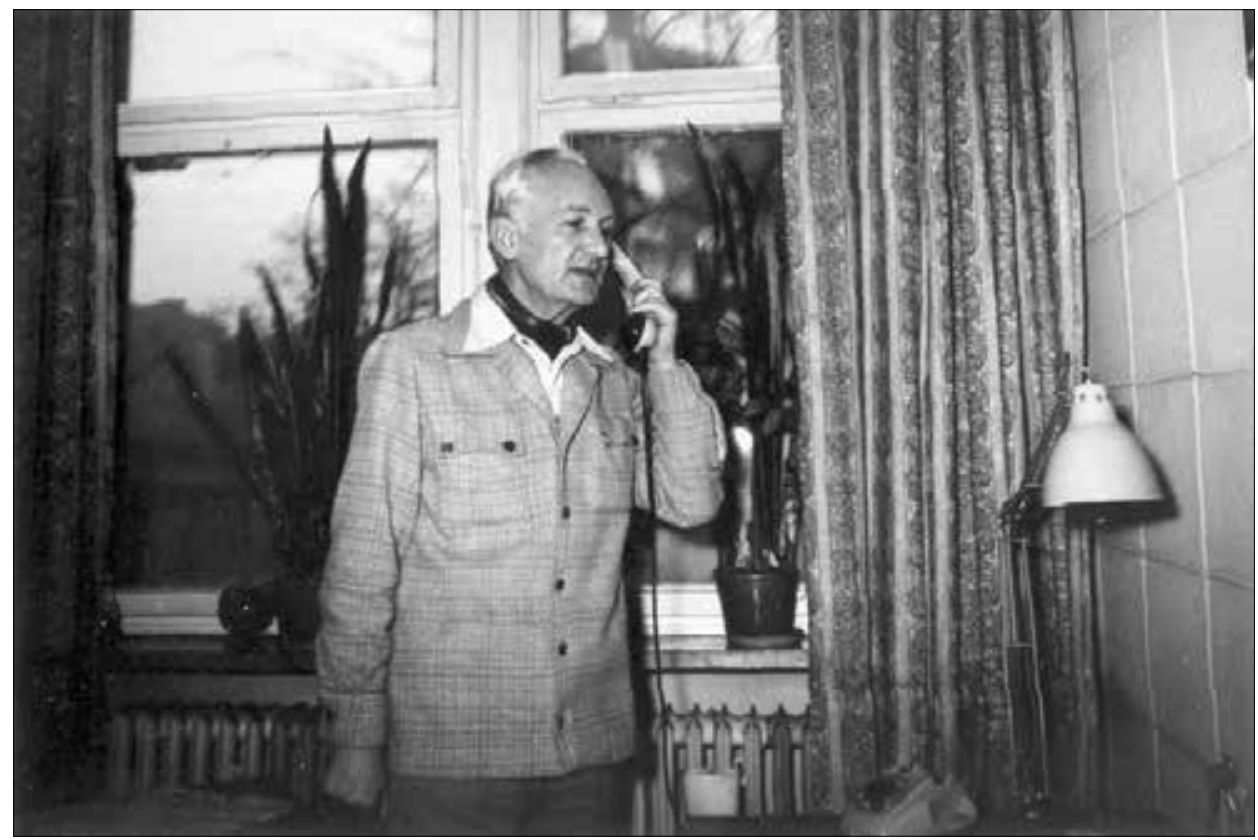

Fig. 4. Prof. J. Żak w swoim gabinecie Prahistorii w Collegium Novum UAM - 1978 r. (archiwum prywatne)

Fig. 4. Prof. J. Żak in his office in the Institute of Prehistory at the Collegium Novum AMU - 1978 (private collection)

Autorytet naukowy Profesora, szacunek oraz szerokie kontakty naukowe, jak na tamte czasy, zwłaszcza z nauką niemiecką, także skandynawską, zaowocowały ścisłą współpracą naukową Instytutu Prahistorii UAM (obecnie WA UAM) z Instytutem Archeologii w Kilonii, konkretyzowanej w wielu inicjatywach badawczych i pracach naukowych, a także wyjazdach studyjnych na Uniwersytet w Kilonii. Prawie wszyscy pracownicy skorzystali z tego okna na świat. Nawiązał również współpracę z krajami skandynawskimi, a także krajami Europy Środkowej i Środkowo-Wschodniej.

Profesor Jan Żak został uhonorowany wieloma nagrodami, spośród których na podkreślenie zasługują: Nagroda Państwowa I stopnia (zespołowa) w 1978 r. za współautorstwo Dziejów Polski oraz dwie nagrody II i III stopnia Ministerstwa Nauki, Szkolnictwa Wyższego i Techniki, Nagroda Sekretarza PAN, Nagroda Naukowa m. Poznania i woj. poznańskiego (w 1973 r.). Natomiast wśród prestiżowych odznaczeń otrzymał Krzyż Kawalerski Orderu Odrodzenia Polski (w 1974 r.), Krzyż Oficerski Orderu Odrodzenia Polski (w 1987 r.), Medal Komisji Edukacji Narodowej (w 1977 r.) oraz liczne odznaczenia regionalne i medale.

Te wszystkie przytoczone fakty składają się na dokonania Profesora Jana Żaka jako wybitnej postaci, jednak zza nich mało widać człowieka. A przecież i w tym względzie był postacią szczególną. Cechowała go wrażliwość na sprawy innych ludzi. Zgromadzeni wokół niego bardzo liczni uczniowie podziwiali go za ducha walki, 


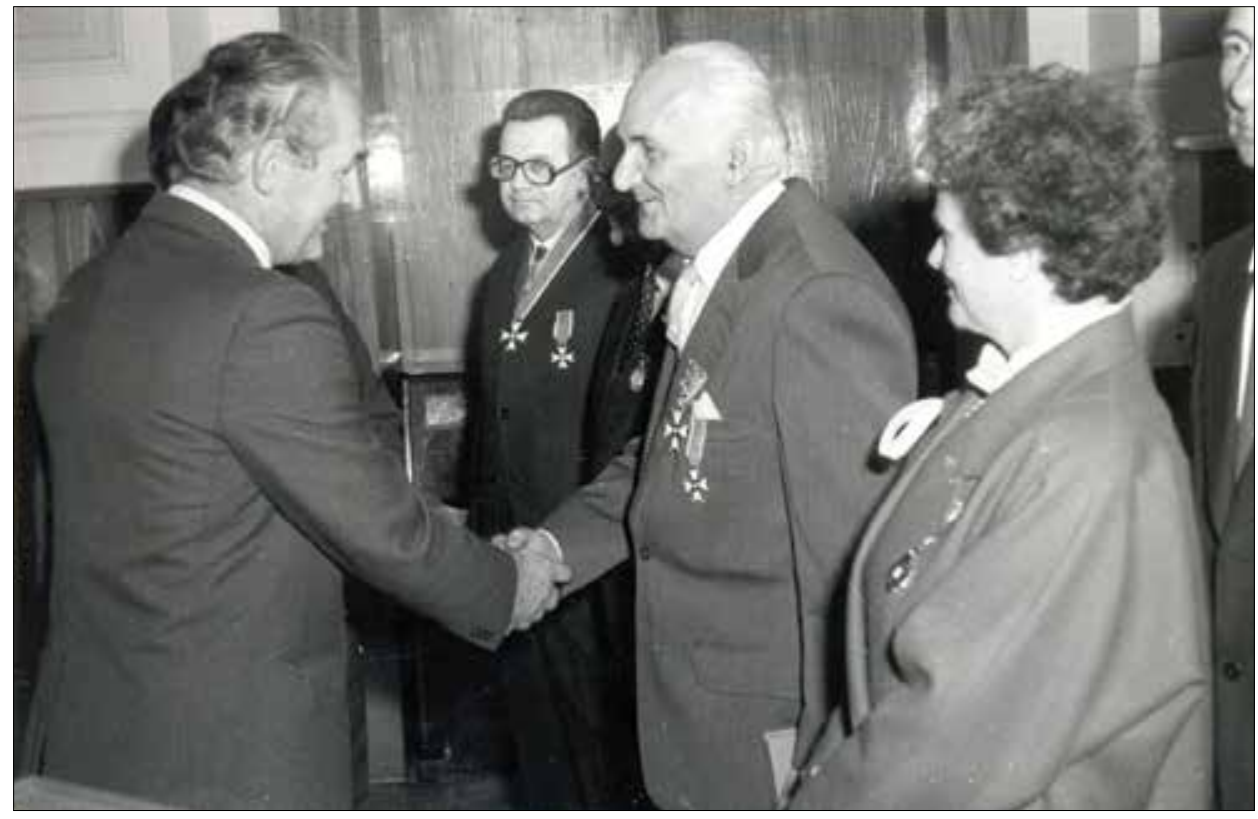

Ryc. 5. Prof. J. Żak odbiera Krzyż Oficerski Orderu Odrodzenia Polski - 14.10.1978 r. w gabinecie Premiera (archiwum prywatne)

Fig. 5. Prof. J. Żak receives the Officer's Cross of the Order of Polonia Restituta - October 14, 1978 in the Prime Minister's office (private collection)

widocznego zwłaszcza w długotrwałej chorobie, ale przede wszystkim za ogromną wiedzę szczególnie na temat średniowiecza europejskiego, co nie zawężało Jego horyzontów myślowych. Wszelkie dyskusje prowadził żarliwie, ponieważ był wielkim erudytą, myślał szybko, błyskawicznie syntetyzował, ale równie szybko przechodził do praktycznych przykładów. Jednak w postawie Profesora było coś, co sprawiało, że bycie Jego uczniem uznawano za wielki zaszczyt. Stworzył bowiem terenową tzw. szkołę bnińską, związaną z badaniami na grodzisku wczesnośredniowiecznym.

Ale przede wszystkim był twórcą poznańskiej szkoły archeologicznej o wyraźnym nastawieniu na metodologię badań archeologicznych. Jego seminaria magisterskie i doktorskie pękały w szwach, a wypromowani już doktorzy nadal się na nich pojawiali, ponieważ mogli się wiele nauczyć od Mistrza, jakim niewątpliwie był Profesor Jan Żak. Prowadził bardzo ciekawe wykłady, starannie i logicznie przygotowane, okraszane dziesiątkami slajdów. Przekazywał wiedzę, do której nikt nie był w stanie wówczas dotrzeć, ponieważ wymagała kontaktów z zachodnioeuropejską archeologią. Na początku mówił wolno, ale w miarę jak upływał czas - przyspieszał, jakby sam odkrywał jeszcze coś nowego w danej problematyce. Był nauczycielem, który pozwalał swoim uczniom na samodzielne myślenie i pracę. Był też człowiekiem idei, zawsze dobro innych przedkładał nad swoje, a Instytut Prahistorii był dla niego dobrem nadrzędnym, z którym się utożsamiał. 


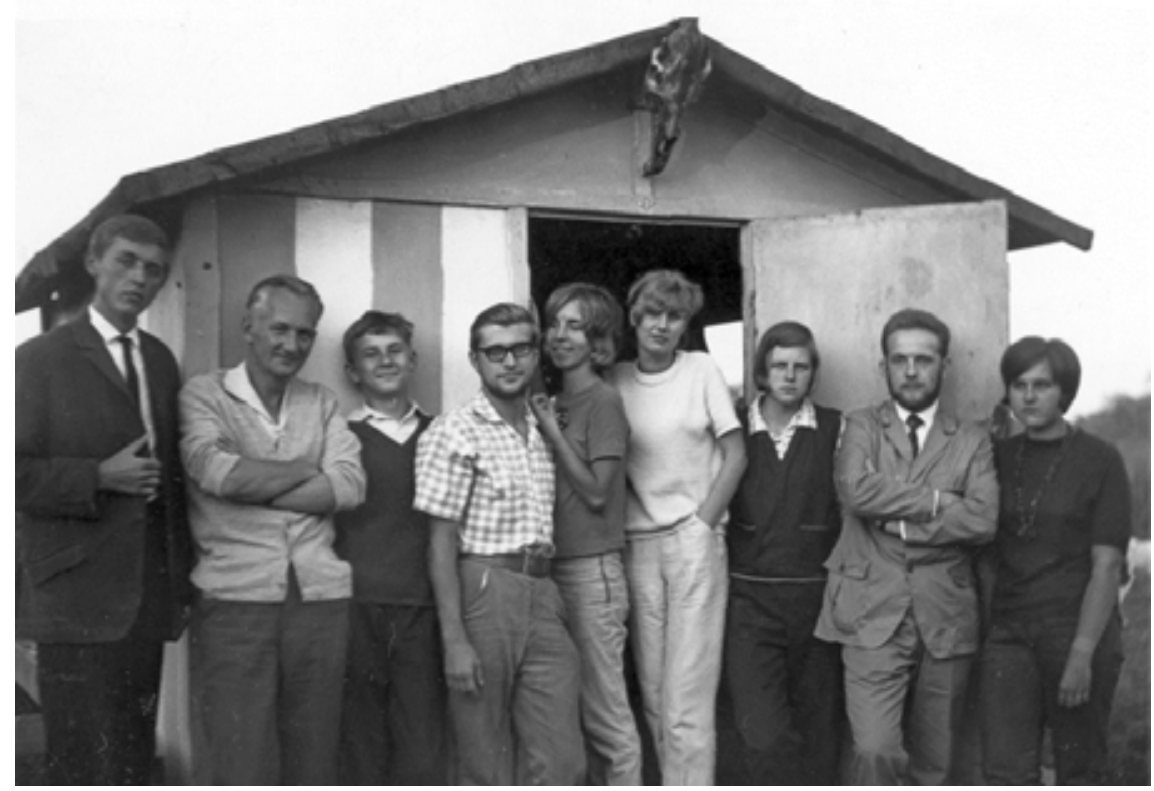

Ryc. 6. Prof. J. Żak z uczestnikami badań archeologicznych na grodzisku w Bninie, woj. wielkopolskie w latach 60. XX w. (archiwum prywatne)

Fig. 6. Prof. J. Żak with the participants of the archaeological research at the stronghold in Bnin, Greater Poland province, in the 1960s of the 20th century (private collection)

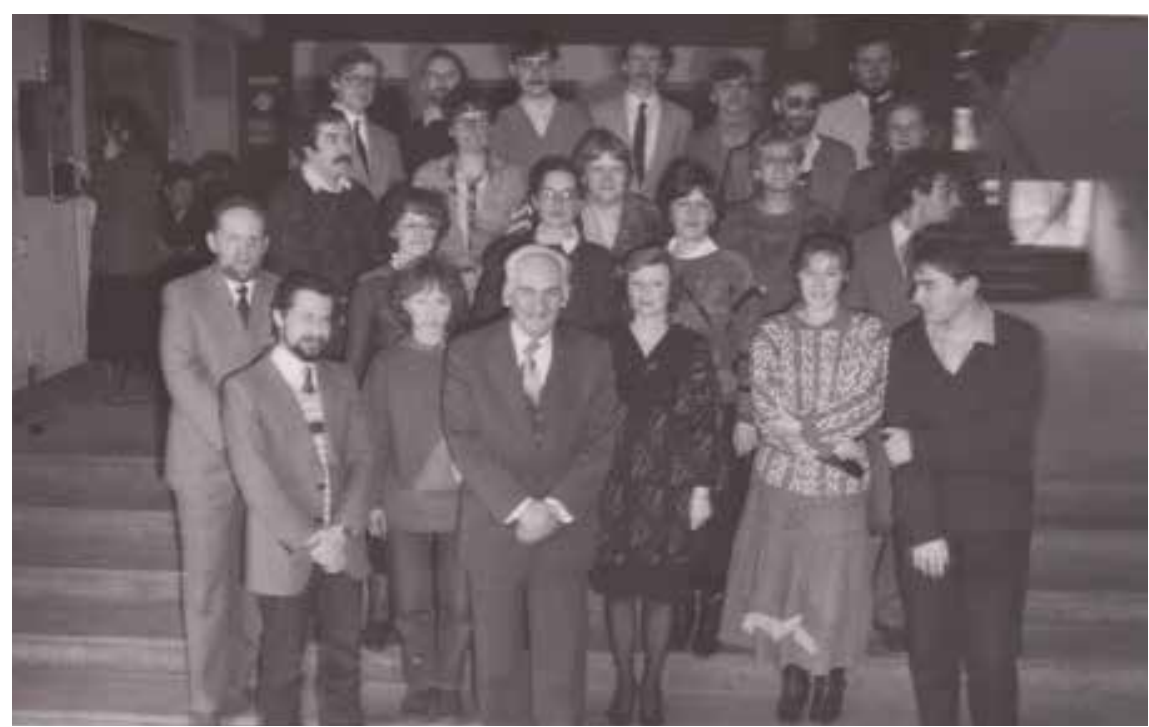

Fig. 7. Jubileusz 65 urodzin Prof. J. Żaka (1988 r.), uwieczniony z pracownikami, studentami w holu Collegium Novum UAM - (fot. Andrzej Pniak)

Fig. 7. Jubilee of the $65^{\text {th }}$ birthday of Prof. J. Żaka (1988), photographed with employees and students in the hall of the Collegium Novum AMU - (photo by Andrzej Pniak) 
Z Profesorem wiązało się wiele anegdot, ale najdłużej przetrwała ta dotycząca Jego wyjazdu na Kongres Unii Nauk Pre- i Protohistorycznych do Meksyku (w 1981 r.). Przygotowywany niezwykle starannie wyjazd (na ile było to możliwe w czasach totalnego kryzysu gospodarczego) na egzotyczny kongres skończył się fiaskiem. Nie chcąc narażać Uczelni na zbyt wysokie koszty podróży (które w przeliczeniu na złotówki przyprawiały wówczas o zawrót głowy), wybrał drogę przez Moskwę, z której miał lecieć do Hawany i dalej do miasta Meksyk, na ów kongres. Ale w Moskwie nie wpuszczono go do samolotu, ponieważ do Hawany jechała drużyna sportowców i nie miało znaczenia, kto jeszcze miał wykupione miejsce na ten lot. Wrócił po dwóch dniach, ku zdziwieniu wszystkich, a Jego bagaż po dwóch miesiącach.

Patrząc na fotografie Profesora Jana Żaka, widzimy najczęściej eleganckiego Pana z klasą.

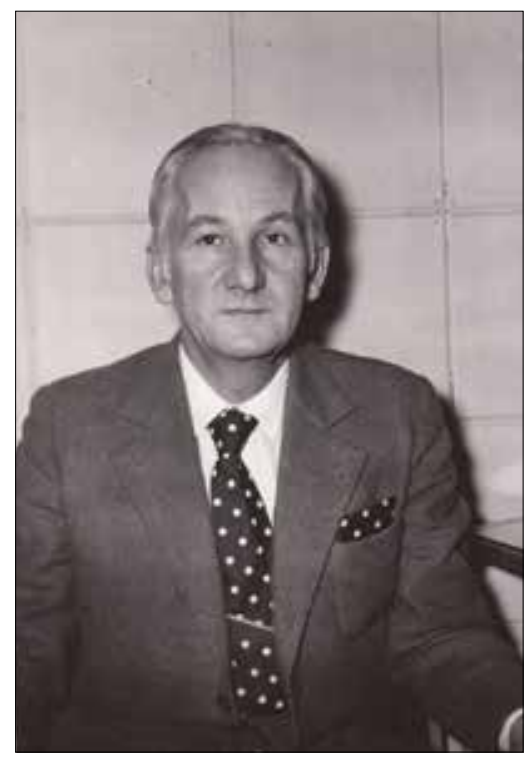

Ryc. 8. Prof. J. Żak na zdjęciu portretowym z 1974 r. (fot. F. Lachowicz)

Fig. 8. Prof. J. Żak in a portrait photo from 1974 (photo by F. Lachowicz)

Ale często idącego zgodnie z modą, ponieważ kurtki w kratę, budrysówki, apaszki nie były mu obce. Na jednej z fotografii został uwieczniony z modnym wówczas papierosem, który zabrał mu zapewne część życia. Niestety poważna, przewlekła i wyniszczająca choroba przerwała je 4 stycznia 1990 r. (zmarł w Poznaniu).

Kiedy przegląda się czarno-białe fotografie z czasów Profesora Jana Żaka, jakby zrobione wczoraj, z sesji naukowych, okolicznościowych spotkań, wizyt gości zagranicznych, wracają wspomnienia.

W serdecznej zadumie pamiętamy Profesora jako prawdziwie Wielkiego Człowieka, Nauczyciela, Mistrza i wówczas ,wielka” nauka jest jedynie tłem. Przedwczesna śmierć pozbawiła Profesora możliwości stania się nestorem UAM, cieszenia się zasłużoną sławą i bycia obdarowywanym kolejnymi zaszczytami, choć i za życia otrzy- 


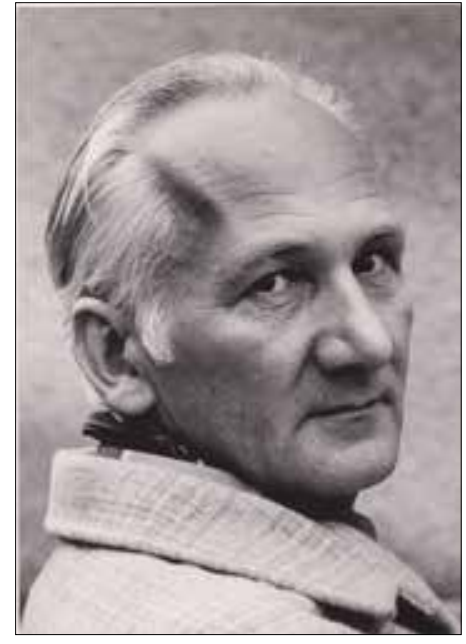

Ryc. 9. Zdjęcie portretowe Prof. J. Żaka z 1977 r. (fot. F. Lachowicz)

Fig. 9. Portrait photo of Prof. J. Żak from 1977 (photo by F. Lachowicz)

mał ich wiele. Wprawdzie po Jego śmierci ukazała się monografia, która stawiała za cel omówienie w jakimś stopniu wszechstronnego dorobku Profesora Jana Żaka, pod znamiennym tytułem, wymyślonym w głównej mierze przez Włodzimierza Rączkowskiego: Archeologia. Paradygmat. Pamięć (Minta-Tworzowska, Rączkowski, 2001a, 2001b). Jednak twórczość Profesora nadal zasługuje na pełniejsze opracowania. Z jednej strony dlatego, że stanowi źródło inspiracji, a z drugiej, że wyprzedzała swoją epokę i niektóre Jego tezy lepiej wpisują się w dzisiejsze rozważania niż ówczesne.

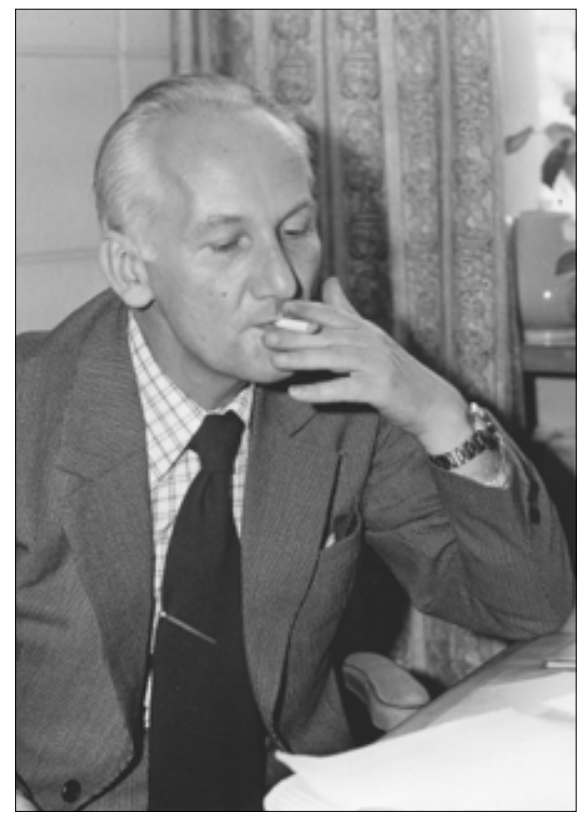

Ryc. 10. Prof. J. Żak z nieodłącznym papierosem Carmenem w gabinecie w Collegium Novum UAM (fot. F. Lachowicz)

Fig. 10. Prof. J. Żak with his inseparable cigarette Carmen in the office at the Collegium Novum AMU (photo by F. Lachowicz) 


\section{TWÓRCZOŚĆ NAUKOWA POD KĄTEM JEGO DYSKUSJI METODOLOGICZNYCH}

Prace naukowe Profesora Jana Żaka miały rozległy charakter, czego wyrazem jest około 200 opublikowanych pozycji. Składają się na nie prace syntetyzujące, monografie, studia, artykuły, sprawozdania z badań wykopaliskowych. Podkreśla się ich wszechstronność erudycyjną i rzetelność analityczną. Profesor był autorem lub współautorem 6 książek, w 8 tomach, oraz monografii źródłowych. Kilkanaście jego studiów i artykułów znajduje się w czasopismach zagranicznych, mianowicie czeskich, niemieckich, francuskich, szwedzkich. Wyniki swej pracy przedstawiał w postaci referatów na kongresach międzynarodowych (w Warszawie, Berlinie, Bratysławie, Pradze, Nicei), również na zjazdach (w Getyndze), a także na wykładach w Szwecji (Lund, Sztokholm), w Danii (Kopenhaga), w RFN (Kilonia, Monachium, Getynga, Moguncja, Kolonia). Wyróżnia go to, że większość publikacji zawiera ważne myśli, oryginalne pomysły na to, jak uprawiać archeologię oraz na szczegółowe kwestie archeologiczne. Niektóre z nich można wręcz uznać za credo myśli i teorii Jana Żaka, często wyraźnie wyprzedzające swoją epokę.

Badania naukowe Profesora koncentrowały się na problematyce wczesnego średniowiecza, zwłaszcza kontaktów społeczeństw zachodniosłowiańskich ze skandynawskimi, a także nad uzbrojeniem i etnogenezą Słowian oraz na problematyce teoretycznej i metodologicznej prahistorii (archeologii). Realizacji tej problematyki służyły zarówno rozległe studia (również w Skandynawii), jak i nowoczesne prace wykopaliskowe, początkowo nad wczesnośredniowiecznym Poznaniem (w 1950 r.), następnie Bninem (gm. Kórnik), wreszcie badania na Pomorzu Środkowym, w ramach ogólnopolskiego programu studiów nad etnogenezą Słowian oraz rekonstrukcją pradziejów tego regionu. Był to temat wiodący w tamtym czasie w archeologii środkowoeuropejskiej.

Początkowo Profesor wiele uwagi poświęcił wczesnośredniowiecznemu Poznaniowi oraz różnym aspektom kultury materialnej, z którymi wiąże się pierwsza monografia Najstarsze ostrogi zachodniostowiańskie. Wczesnośredniowieczne ostrogi o zaczepach haczykowato zagiętych do wnętrza (Żak, 1959). Zagadnienie to podjął ponownie (wraz z L. Maćkowiak-Kotkowską) blisko 30 lat później, dając temu wyraz w monografii Studia nad uzbrojeniem środkowoeuropejskim w VI-X wieku. Zachodniobattyjskie i stowiańskie ostrogi o zaczepach haczykowato zagiętych do wnętrza (Żak, Maćkowiak-Kotkowska, 1988). Praca ta stanowiła dojrzałe ujęcie zarówno pod względem teoretycznym, jak i przedmiotowym na tle szerszej problematyki.

Problematyka skandynawska odgrywała podstawową rolę w pracach Profesora, czego wyrazem są monografie: Studia nad kontaktami spoleczeństw zachodniostowiańskich ze skandynawskimi od VI do VIII wieku (Żak, 1962), Importy skandynawskie na ziemiach zachodniostowiańskich od IX do XI wieku (Żak, 1963) oraz Wczesnofeudalna Skandynawia (Żak, 1969). Prace te są głęboko erudycyjne i w znacznej mierze pionierskie na gruncie polskim. 
Poważny udział w twórczości Profesora Jana Żaka zajmowała problematyka niemcoznawcza i słowianoznawcza, której poświęcił m.in. pracę Słowianie i Germanie w prahistorii polskiej i niemieckiej (Żak, 1974), a w ich uzupełnieniu artykuły i studia dotyczące m.in. problemów metodologicznych dziejów Niemiec, początków ujęć syntetyzujących pradzieje społeczeństw zamieszkujących międzyrzecze Odry i Renu, a także etnogenezy i topogenezy Słowian w świetle prahistorii.

Nie sposób pominąć zainteresowań i studiów Profesora nad procesami osadnictwa zarówno w Wielkopolsce, jak i na Pomorzu. Efektem były publikacje, które redagował oraz był współautorem 4-tomowej serii Materiaty do studiów nad osadnictwem bnińskim, poświęconej wyjaśnieniu roli grodów niekasztelańskich w kolejnych tomach: Grodzisko wklęste, Grodzisko stożkowate, Podgrodzie, Mikroregion bniński. Profesor Jan Żak redagował również Studia i materiały do osadnictwa Pomorza Środkowego na przełomie er (Żak, 1980a), jako efekt jego namysłu nad osadnictwem i próba oryginalnego ujęcia, które docenione zostało dopiero współcześnie. Podjął także próbę oryginalnego ujęcia syntetyzującego dzieje społeczeństw nad Odrą i Wisłą w pracy Ziemie polskie w starożytności we wczesnym średniowieczu, stanowiącej istotny element Dziejów Polski (pod redakcją J. Topolskiego: Topolski, 1975; Żak, 1975). Ostatnia z tych prac była Jego drogą do syntezy prahistorii. Nawiązał w niej do bogatego dorobku poznańskiego ośrodka prahistorycznego i historycznego oraz do osiągnięć metodologicznej szkoły poznańskiej i zaproponował spójną wizję pradziejów tych społeczeństw.

Ważnym nurtem rozważań Profesora Jana Żaka była teoria i metodologia archeologii i prahistorii, którą propagował i której podstawy tworzył jako jeden z nielicznych polskich archeologów. Występował zdecydowanie przeciwko archeologii pozytywistycznej w wersji dyfuzjonistycznej szkoły kulturowo-historycznej. Dlatego wydaje się, że był to najważniejszy powód, dla którego zwrócił się ku poznańskiej szkole metodologicznej, jako jedynej wówczas alternatywie dla pozytywizmu. We wszystkich pracach naukowych uwidacznia się konsekwencja w postępowaniu badawczym Jana Żaka, a także docenianie roli jasnych podstaw teoretycznych i metodologicznych. Postawa ta najwyraźniej występuje w modelu przedmiotowym, jak i w studiach nad osadnictwem, mimo że nie znajdowały się one w centrum zainteresowań Profesora. Poszukiwał on teorii odgrywającej rolę wyjaśniającą wobec tej problematyki, która odnosiłaby się zarówno do zjawisk ujmowanych w płaszczyźnie synchronicznej, jak i diachronicznej.

$\mathrm{Na}$ temat osadnictwa w aspekcie metodologicznym Profesor wypowiedział się w dwóch artykułach: O studiach osadniczych (Żak, 1977) oraz Uwagi metodologiczne nad problemem osadnictwa (Żak, 1985a), a także angażował się w polskie tłumaczenie pracy Herberta Jankhuna o osadnictwie (Jankhun, 1983). Zainteresowania osadnictwem były wówczas swoistym rysem środkowoeuropejskiej archeologii. J. Żak w Uwagach metodologicznych... określił osadnictwo jako historyczną, bo podlegającą przemianom formę bytu społecznego, będącą rezultatem ukierunkowanej działalności społeczeństwa $\mathrm{w}$ określonej epigeosferze, w której zaistniały przynajmniej znośne warunki bytowania. Czynnik rozwoju stanowiła praktyka społeczna. Efektem 
procesów osadniczych była wg niego socjoekosfera, dlatego działalność ludzka wyznacza ramy osadnicze. Tak więc ujmował osadnictwo z perspektywy relacji aktywny człowiek - gospodarka - środowisko. Uważał, że osadnictwo stanowi egzemplifikację relacji społeczeństwa do jego naturalnego środowiska przestrzennego. Wypowiadał się przeciwko determinizmowi geograficznemu i ujęciom zdroworozsądkowym tej problematyki. W ideach Profesora również $\mathrm{w}$ tym zakresie widoczna jest odmienność ujmowania tej problematyki w kontekście poglądów funkcjonujących wówczas w archeologii.

Ważnym problemem teoretycznym, metodologicznym i praktycznym była kwestia kontynuacji osadnictwa/bytu społecznego na obecnych ziemiach polskich w V/ VI w. n.e. Podjął on próbę przeformułowania pozytywistycznego problemu ,ciągłości/nieciągłości" osadniczej, rozumianego w kategoriach ciągłości występowania zabytków w nieprzerwanej sekwencji warstw kulturowych na danym obszarze. Profesor wprowadził jego rozumienie teoretyczne jako zróżnicowany czasoprzestrzennie i funkcjonalnie proces przemian. Ujął ten problem w 1985 r. jako kwestię kontynuacji lub dyskontynuacji bytu społecznego i kulturowego (artykuł zatytułowany: $O$ kontynuacji/dyskontynuacji społecznej i kulturowej na ziemiach nadodrzańskich i nadwiślańskich w V-V/VI wieku n.e. (Żak, 1985b). Wskazał na najistotniejszą kwestię na tym poziomie rozważań, a mianowicie przyjęcie krótkiej lub długiej chronologii. To ona Jego zdaniem decyduje o przyjęciu istnienia hiatusu lub jego braku. Zaproponował model ujmowania zjawisk kryzysowych, które miały miejsce na przełomie starożytności i wczesnego średniowiecza. Zjawiska kryzysowe dotyczyć miały gospodarki, kultury, przy zachowaniu tej samej substancji ludzkiej. Jan Żak uważa, że powstała wówczas podstawowa sprzeczność między socjokulturą a socjoorganizacją; więzi o charakterze plemiennym zostały zastąpione przez związki terytorialne. W tym duchu prowadził już wcześniej refleksję nad obrazem etnogenezy Słowian, tworzonym przez prahistorię niemiecką i polską, już w pracy z 1974 roku Stowianie i Germanie w prahistorii polskiej i niemieckiej (Żak, 1974). Jednak w omawianym artykule dostrzegał wyraźnie nieefektywność badań nad etnogenezą w następujących cechach tych badań: w pozytywistycznym modelu nauki; w korelacji kultur archeologicznych ze wspólnotą językową (z etnosem), co jego zdaniem wymagało pogłębionych studiów; w podjęciu rekonstrukcji etnokultury (prawie wszystkie studia stawiały znak równości między wspólnotą kulturową a wspólnotą językową i wspólnotą etniczną dla okresu plemiennego dziejów ludzkości); doborze źródeł - fetyszyzacja źródeł archeologicznych a pomijanie źródeł językoznawczych. Spowodowało to dyskusję nad rozumieniem „hiatusu”, w której to kwestii wypowiadał się głównie Jan Żak, także Stanisław Tabaczyński czy Anna Pałubicka z Tabaczyńskim (Tabaczyński, 1985; Pałubicka, Tabaczyński, 1986). Trudność z tym pojęciem i jego paradoksalny charakter polega na tym, że odwołując się do Michaela Foucaulta i tez z jego Archeologii wiedzy z 1977 r. (Foucault, 1977) - pełni ono funkcję zarówno przedmiotową, jak i podmiotową (odnosi się jednocześnie do sfery bytu i poznania).

Profesor zajmował się również tematyką studiów w duchu kognitywnym w archeologii, co sprawiało, że wyprzedzał on swoją epokę o kilka długości. Prowadził 
refleksję teoretyczną nad pradziejami (Żak, 1975c) i w duchu swoich przemyśleń pisał o ziemiach polskich w pradziejach i wczesnym średniowieczu (Żak, 1975a). Interesowała go także refleksja człowieka pradziejowego i nowożytnego na temat własnej przeszłości, co zawarł w artykule z 1975 r. Próba przedmiotowego modelu kultury społeczeństw młodszego i schyłkowego paleolitu (strefy śródziemnomorskiej) (Żak, 1975b). W duchu scjentystycznym zaproponował periodyzację tej refleksji, mającą odbijać różnice w myśleniu społeczeństw pradziejowych. Podstawową różnicę w powyższej refleksji dostrzegał między społecznościami zbieracko-łowieckimi a wczesnorolniczymi; kolejny przełom to społeczeństwa wczesnoklasowe - najstarszych cywilizacji; refleksja klasowych społeczeństw antycznych strefy śródziemnomorskiej; wreszcie społeczeństwa klasowe zachodnioeuropejskie. Profesor zrealizował jedynie część tego zamysłu, a mianowicie przedstawił swoją interpretację refleksji społeczeństw łowiecko-zbierackich strefy śródziemnomorskiej. Model ten zbudował na następujących założeniach: 1) sposób wytwarzania, technologia określa całość życia społecznego; 2) potencjał produkcyjny determinuje relacje między wytwórcami; 3) całokształt obiektywnych elementów życia społecznego i bytowania determinuje świadomość. Świadomość tych społeczności ujmował jako z jednej strony odbicie warunków życia tych ludzi, z drugiej - jako regulator tegoż życia, opleciony wokół instytucji rodowych i plemiennych. Na świadomość tę składała się wiedza, magia, ideologia rodowo-plemienna i religia. Ten niezwykły projekt przerwała jego śmierć.

\section{JAKA METODOLOGIA UNIWERSYTECKA W POZNANIU PO 30 LATACH?}

Prace uniwersyteckich metodologów archeologii charakteryzują się różnorodnością, ale dotyczą one refleksji nad teorią i metodologią archeologii, zapoczątkowanej przez Jana Żaka w jego dążeniach do wyjścia poza pozytywistyczny (indukcjonistyczny, doświadczalny) model wiedzy archeologicznej (Żak, Minta-Tworzowska, 1987). Archeologia uniwersytecka poznańska należała w tym względzie do niewielu ośrodków w Polsce rozwijających tę tematykę. Profesor J. Żak rozwijał zagadnienia, którymi żyła archeologia w latach 70. i 80 . XX w., a mianowicie etnogenezę Słowian, osadnictwo, a zwłaszcza jego kontynuacja/dyskontynuacja (Żak, 1980, 1985). Interesowała go tożsamość archeologii i jej miejsce wśród innych nauk humanistycznych (Żak, 1966, s. 69-75) czy refleksja człowieka pradziejowego, którym to ujęciem wyprzedził swoją epokę (Żak, 1974-1975). Stosując interpretację humanistyczną, dostrzegał zasadnicze różnice w myśleniu i ujmowaniu świata przez ludzi pradziejowych i nowożytnych, ukazując, w jaki sposób sprzeczności wewnętrzne prowadzą do zmian. Świadomość ujmował jako odbicie warunków życia ludzi oraz jako regulator tego życia (Żak, 1974-1975). Tym samym ukazywał inny model uprawiania archeologii.

W ostatnim czasie ukazały się artykuły nawiązujące bezpośrednio do twórczości metodologów archeologii na Uniwersytecie w Poznaniu. Najtrudniej wewnętrznie 
stawiać diagnozę, w jakim miejscu jesteśmy (por. próbę takiej diagnozy: Minta-Tworzowska, Pawleta, 2013). Dlatego bardziej istotna w tym względzie jest zewnętrzna diagnoza w postaci obszernego i wnikliwego artykułu Henryka Mamzera z 2020 r. zatytułowanego „Mowa obrończa”, metodologii archeologów Uniwersytetu im. Adama Mickiewicza w Poznaniu (Mamzer, 2020), w którym Autor nakreślił główne kierunki badań w/w archeologów, zajmujących się tą tematyką jako zasadniczą w swoich badaniach naukowych (Mamzer, 2020, s. 110-148). Użycie metafory „mowa obrończa” jest wymowne, ale chodzi tu o przedstawienie racji tej metodologii, a nie o potoczne rozumienie obrony. H. Mamzer starał się scalić tak różne, polifoniczne poglądy w pewną całość, co daje szersze spojrzenie na tę kwestię. Znając temperament badawczy Henryka Mamzera, nietrudno się domyślić, że jego rozważania są pogłębione o szeroką refleksję filozoficzną i antropologiczną, a w tym kontekście zarysował elementy tej metodologii. Nie odnosząc się do obszernych wywodów H. Mamzera, nietrudno zauważyć i zgodzić się z diagnozą, że metodolodzy, uczniowie prof. Żaka, poszli dwiema różnymi drogami w jej rozwijaniu. Sama również zadałam pytanie Czy jesteśmy tam, gdzie chcielibyśmy być? Modernistyczne dążenia a postmodernistyczna rzeczywistość archeologii. Kilka uwag o metodologii archeologów na Uniwersytecie im. Adama Mickiewicza w Poznaniu (Minta-Tworzowska, 2021).

Uczniowie Profesora Żaka, a potem kolejne pokolenie badaczy starało się poszukiwać odpowiedzi na pytanie, które ostatnio zadał explicite Henryk Mamzer (2020) po co nam metodologia i teoria archeologii? Przedstawiciele archeologii uniwersyteckiej starali się pokazywać nieodzowność teorii archeologii; nawiązując w latach 80 . $\mathrm{XX}$ w. do rodzimych teorii (np. tego, co oferowała metodologiczna szkoła poznańska), powiązanych z ideą archeologii jako nauki historycznej, a później, od lat 90. XX w., a zwłaszcza po roku 2000 do rozwiązań szerszych, zapożyczonych z nauki światowej (m.in. Minta-Tworzowska, 2017).

Dorobek archeologów z UAM, co było dość wcześnie zauważalne, dzieli się na dwie odmienne postawy metodologiczne: humanistyczną oraz o nachyleniu przyrodoznawczym. Obie te postawy zostały wypracowane w ramach metodologicznej szkoły poznańskiej, której twórcami byli Jerzy Kmita, Leszek Nowak, a na gruncie historii Jerzy Topolski. W archeologii propagatorami nowych poglądów był Jan Żak ${ }^{1}$ w Poznaniu, a w Warszawie w PAN Stanisław Tabaczyński. Śladem metodologicznej szkoły poszli wychowankowie prof. J. Żaka pracujący na UAM, a mianowicie Danuta Minta-Tworzowska, Włodzimierz Rączkowski, Arkadiusz Marciniak. W tym duchu, choć już o nastawieniu właściwym archeologii zachodnioeuropejskiej, piszą również swoje prace Michał Pawleta (2016) czy Lidia Żuk (2019).

To co zmieniło się bezsprzecznie przez 30 lat, to uległy poszerzeniu pola badawcze, którymi zajmują się metodolodzy i teoretycy archeologii na Uniwersytecie w Poznaniu. Rozumienie samej metodologii wynika z założeń metodologicz-

${ }^{1}$ Profesor Jan Żak w 1982 r. powołał do życia pierwszy i jedyny na polskich uniwersytetach Zakład Historii i Metodologii Prahistorii w Instytucie Prahistorii (1982 r.), który zakończył swoje formalne istnienie, kiedy do życia powołano Wydział Archeologii UAM (2019), bez struktury wewnętrznej. 
nej szkoły i za J. Kmitą metodologia to sposób „jak należy wykonać poszczególne czynności badawcze [...], aby można było otrzymać efekty możliwie najbardziej wartościowe poznawczo" (Kmita, 1977, s. 112). A więc dotyczy ona reguł postępowania badawczego, teorii prowadzących do uzyskania odpowiednich efektów poznawczych (Kmita, 1971). Odwołując się do bardziej współczesnych poglądów, np. za Henrykiem Mamzerem (2020, s. 123), metodologia to "nie tylko jako wydobywanie $\mathrm{z}$ chaosu. To porządkujące ujednolicenie czegoś, co jednolitością nie było"; przy czym „chaos” został użyty w roli metafory. Taki porządkujący charakter mają wszelkie prace będące refleksją nad przeszłością, w tym społeczną (Tabaczyński, Marciniak, Cyngot, Zalewska, 2012). Podstawy metodologiczne zostały rodzime, jednak inspiracje nauki zachodniej mają nieodparty urok i dynamizm i to ich wpływ wydaje się najważniejszy w ostatnich 30 latach (Marciniak i in., 2011). Tę niełatwą relację ujęłam jako mieszczącą się między wspólnotą inspiracji płynących zwłaszcza po 1989 r. z kręgu nauki anglosaskiej a odrębnością tradycji silnie oddziałującej na archeologię, jej tożsamość w danym kraju, ale także na jej zachowawczość (Minta-Tworzowska, 2002). Dlatego jedni chcą, aby archeologia była antropologią pradziejów, lecz wpierw antropologią, dopiero później pradziejów, np. Kowalski, (2015, s. 143), i proponują archeologię kulturoznawczą. Inni uważają, że powinna być powiązana z naukami historycznymi, jeszcze inni, że powinna być antropologią kulturową/społeczną. Natomiast Ian Hodder $(1990,1991)$ uważa, że archeologia jest po prostu archeologią i tak należy ją rozumieć.

\section{Teoria}

Metodologia ściśle łączy się z przyjmowaną teorią archeologii, najogólniej rozumianą jako sposób myślenia o przeszłości. Standardom teoretycznym w polskiej archeologii poświęcono dużo uwagi, podejmując próby ich diagnozy (Minta-Tworzowska, Rączkowski, 1996, 2007). Za Jerzym Kmitą, a zwłaszcza za Jerzym Topolskim zakładamy pierwotność wiedzy teoretycznej wobec empirycznej, co wybrzmiewa jednoznacznie zwłaszcza w pracach W. Rączkowskiego, zwłaszcza w Archeologii lotniczej (2002), także A. Marciniaka (2012a, 2012b, 2012c), również M. Pawlety (2016). Sama również pisałam $w$ duchu niezbędności i pierwotności teorii w jakichkolwiek badaniach archeologicznych, w tym w odniesieniu do zastosowania klasyfikacji czy typologii (Minta-Tworzowska, 1994, s. 14) oraz czy archeologia współczesna „potrzebuje” teorii (Minta-Tworzowska, 2015a).

\section{Relacje teorii wobec metody}

Istotnym tematem metodologicznym była relacja: teoria wobec metody i praktyki badawczej. Na uwagę zasługują prace Włodzimierza Rączkowskiego na ten temat, w których rozważał znaczenie metod nieinwazyjnych, a zwłaszcza zdjęć lotniczych 
(Rączkowski, 2002). Prace W. Rączkowskiego i jego uczniów są nastwione głównie na interpretację, zwłaszcza artykuł Interpreting Archaeological Features on the Wieprza River Floodplain, West Pomerania, Poland (Banaszek, Rączkowski, 2019) wpisuje się w to jednoznacznie. W ostatnim czasie ukazał się artykuł W. Rączkowskiego (2017a) Praktyki badawcze archeologów: kilka refleksji o wykorzystywaniu metod nieinwazyjnych, w którym po raz kolejny i dobitnie Autor wskazuje, jaką doniosłą rolę pełnią metodologiczne fundamenty w badaniach interdyscyplinarnych, do której to roli pretenduje metoda interpretacji zdjęć lotniczych. Wokół tych relacji teorii, metody i praktyki zbudowana jest narracja kolejnych ważnych prac W. Rączkowskiego wykorzystania zdjęć lotniczych do różnych krajobrazów, w tym historycznych miast i ich wizualizacji (Rączkowski, 2017b, 2017c, 2020a, 2020b). Autor nie stroni w nich od dyskursu budowanego wokół metafor w odniesieniu do krajobrazów: stosuje metaforę ,,anatomii pustki” (Kolenda, Rączkowski, 2018), „rzeki i grzęzawiska” (Rączkowski, 2018) albo „mocy lub nędzy wizualizacji” danych teledetekcyjnych (Rączkowski, 2020a).

Tematyka ta łączy się bezpośrednio z szerszym pytaniem dotyczącym sposobów przedstawiania w archeologii (Marciniak, 2012c) i dylematów z tym związanych. W tym zakresie uwidaczniają się dążenia do łączenia płaszczyzny humanistycznej z owym przyrodoznawczym nachyleniem, co widoczne jest w pracach A. Marciniaka, dotyczących badań na osadzie neolitycznej w Çatalhöyük (Düring, Marciniak, 2005; Marciniak, 2013; 2015b; Marciniak i in., 2015). Studia powyższe nad społeczeństwem neolitycznym na unikatowym stanowisku archeologicznym w połączeniu z poszukiwaniem rozwiązań teoretyczno-metodologicznych pozwoliły Autorowi wypracować model badań w polskiej archeologii, który sam określa jako „,społeczną zooarcheologię" (Marciniak, 2005, 2006, 2011, 2015a).

\section{Źródło - konstrukt kulturowy}

Swoistą soczewką skupiającą problemy metodologiczne poznańskich metodologów była prowadzona przez wiele lat refleksja nad źródłami archeologicznymi/ewidencją archeologiczną, zwłaszcza refleksja nad tematyką źródeł archeologicznych, a w tym obszarze widoczne jest dominujące nastawienie humanistyczne, jednak w wydaniu niektórych badaczy o nachyleniu biologicznym. Na uwikłanie podejścia do źródeł w nasz ludzki, kulturowy ogląd wskazują w zasadzie wszelkie prace (Rączkowski, 2002; Marciniak, 1996; Minta-Tworzowska, 1998). Uważam, że w odbiorze rzeczy (owych artefaktów) jesteśmy uwikłani w naszej kulturze, wartościach, a nawet spojrzeniu (Minta-Tworzowska, 2011; Minta-Tworzowska, Pawleta, 2013).

Źródło archeologiczne w ujęciu W. Rączkowskiego (2011) można sprowadzić do kulturowego charakteru źródła. Ten sam pogląd jest także moim poglądem (Minta-Tworzowska, 1998, 2011). Natomiast nachylenie przyrodoznawcze w podejściu do źródeł reprezentuje Arkadiusz Marciniak (1996, 2005, 2006, 2011, 2020), skłaniając się do idei łączenia perspektywy humanistycznej z przyrodoznawczą, reprezentowaną przez archaeological sciences, czyli perspektywy procesualnej z postprocesualną. 
Moim zdaniem wszyscy jesteśmy konstruktywistami. Mimo owego nachylenia przyrodoznawczego, warto mieć świadomość, że humanistyczne podejście może uwolnić do scientyzmu archeologii procesualnej, który zakrywa treści nieutylitarne, jak znaki, symbole, ideologie, które są najważniejszymi własnościami kultury budującej naszą wiedzę (Marciniak, 1996; Minta-Tworzowska, 2000; Rączkowski, 2002).

\section{Modernizowanie się świata i co po modernizmie?}

Istotna z perspektywy obecnych czasów jest tematyka, którą można ująć: „Relacje przeszłość - teraźniejszość w aspekcie modernizowania się świata i tego, co po modernizmie" (Minta-Tworzowska, 2021). Zakładając, że ukształtował nas modernizm, to jednak rzeczywistość postmodernistyczna, w której funkcjonujemy, wyznacza pewne ramy kształtowane przez relacje człowiek a rzeczy, ,przycinające” nasze modernistyczne nadzieje, ale otwierające nas na inne, nowe możliwości, nowe pola badawcze, jakimi są np. symbolizm, znakowość kultury ludzkiej, kwestie dziedzictwa archeologicznego. Podstawową tezą teraźniejszości jest to, że właśnie teraźniejszość nadaje sens przeszłości, ponieważ jej obraz jest konstruowany tu i teraz. Znajduje to odzwierciedlenie w wielu pracach (Rączkowski, 2011; Minta-Tworzowska, 2000b; Marciniak, 2012a, 2012b, 2012c). Wyraźnie konstruktywistyczny charakter, nastawiony na interpretację humanistyczną, mają prace autorstwa/współautorstwa W. Rączkowskiego (2018; także: Kolenda, Rączkowski, 2018; Banaszek, Rączkowski, 2020), opowiadające się po stronie postprocesualizmu.

Świat archeologii postprocesualnej czy nawet post-postprocesualnej jest już światem oczywistym dla Michała Pawlety (2016), Lidii Żuk (2019) i całego grona młodszej generacji archeologów, wręcz zafascynowanych teorią i metodologią archeologii w różnych jej odmianach, którym dali wyraz w zrealizowanych pracach doktorskich, a niektórzy w habilitacyjnych. Wymienię tu: Łukasza Banaszka, Adrianę Ciesielską, Mariusza Drzewieckiego, Kaspra Hanusa, Anny Jankowiak, Grzegorza Kiarszysa, Dawida Kobiałki, Mikołaja Kostyrko, Magdaleny Matczak, Maksymiliana Frąckowiaka, Patrycji Filipowicz, Pawła Polkowskiego, Rafała Zapłaty i wielu innych.

Reorientacja postmodernistyczna, inaczej ponowoczesna - jak ją określa m.in. Anna Pałubicka (2018) - w archeologii współczesnej preferuje, jak się wydaje, pięć podstawowych tematów: a) relatywizację prawdy, wiedzy i znaczenia, b) rozdrobnienie wielkiej narracji, c) relacje między agency a dyskursem, d) pluralizm, wielogłosowość i heterogeniczność oraz (e) różną retorykę i style pisania. Przede wszystkim poszerza pole badawcze o kolejne nowe czy wcześniej zmarginalizowane tematy. Szczególną pracą, która wychodzi naprzeciw zagadnieniom współczesnych czasów (tych, które określam jako postprocesualne i post-postprocesualne) jest oryginalne dzieło Michała Pawlety z 2016 r. Przeszlość we wspótczesności. Studium metodologiczne archeologicznie kreowane przeszłości w przestrzeni społecznej. Ważne miejsce w tym aspekcie, także jako pole badawcze, zajmuje krytyczna refleksja dotycząca zarządzania dziedzictwem archeologicznym, a zwłaszcza jego upowszechnianiem 
i upublicznianiem. Znajdując ożywcze inspiracje w nurcie określanym jako archeologia publiczna i wspólnotowa (Pawleta, 2020). Istotne są społeczno-kulturowe zapotrzebowania na kreowane przez archeologię wizerunki przeszłości, społeczne oczekiwania względem tej dyscypliny, a także zdolność archeologii do odpowiedzi na wyzwania współczesnego świata i uczestniczenie w dialogu społecznym (Pawleta, 2017, 2019, 2020). Drogę tę kontynuuje praca Dziedzictwo we wspótczesnym świecie. Kultura, natura, człowiek (Marciniak i in., 2018).

Kolejnym nowym polem badawczym, które otworzyło się wraz z postprocesualizmem w archeologii, stanowi dyskurs pamięci. Wpisują się weń rozważania Lidii Żuk (2015, 2019), dotyczące relacji krajobrazu archeologicznego (rozumianego jako palimpsest) wobec pamięci. L. Żuk skupiła się na aktualizującej roli pamięci, na pamięci społecznej i procesach upamiętniania jako istotnych dla praktyki badawczej archeologii i łączących się z materialnością miejsc pamięci. Powiązanie monumentów z pamięcią nastąpiło wskutek przyjęcia przez Autorkę założenia, że przez konstruowanie trwałych form społeczności (pradziejowe) wyrażały chęć trwałego przekształcenia przestrzeni i wpisania w nią istotnych dla niej znaczeń w sposób narzucający interpretację kolejnym pokoleniom. Problematyce pamięci w kontekście archeologii, zwłaszcza jej „zapisu społecznego”, budowania „sedymentów” tożsamości w postaci grobów, poświęciłam również nieco uwagi (Minta-Tworzowska (2013, 2015b). Jednak przede wszystkim w podobnym duchu jak L. Żuk, ale w odniesieniu do kręgów kamiennych na Pomorzu jako „miejsc pamięci”, napisał M. Pawleta (2015).

\section{To w jakim miejscu się znajdujemy?}

Obawy towarzyszące archeologom w związku z postprocesualizmem, zwłaszcza dotyczące relatywizmu, zaowocowały tym, że w latach 2009-2011 niektórzy z nich zaczęli dostrzegać wyraźne symptomy kolejnego zwrotu, czyli „post-postmodernistycznego", który w archeologii przybiera postać ontologicznego zwrotu ku rzeczom w postaci posthumanistycznego materializmu (Olsen, 2013; Olsen i in., 2012), a który znajduje szczególny wyraz w idei tzw. archeologii symetrycznej (Minta-Tworzowska, 2020), ale także w neodarwinizmie. Bjornar Olsen na kanwie „powrotu do rzeczy” czy w „obronie rzeczy” przypisuje rzeczom sprawczość. Postuluje, aby skupić się już nie na tym, jak człowiek wykorzystuje przedmioty materialne, ale na tym, jak one mu to umożliwiają z powodu swych właściwości, afordancji.

W latach 80. i 90. XX w. w archeologii przetoczyła się debata na temat procesualizmu, zwłaszcza na temat tego, co nadchodziło jako reakcja na niego, oferująca relatywizm, którego obawiano się najbardziej. Łączono postmodernizm w archeologii z archeologią postprocesualną, choć relatywizmu obawiali się nawet zwolennicy tych zmian.

Takie pobieżne zdiagnozowanie i wymienienie głównych tematów wskazuje wyraźne na bardzo duże różnice między metodologią sprzed 30 lat a obecną, mimo kontynuowanych pewnych ogólnych założeń, to nie można zaprzeczyć, że wyparcie 
modernizmu przez postmodernizm, a następnie post-postmodernizm nie mogło być bez wpływu na obecny kształt teorii i metodologii archeologii, również w Poznaniu.

Natomiast prawie wszyscy są zgodni, że współczesna archeologia mniej skupia się na pozycjonowaniu poszczególnych archeologów w kategoriach procesualny, postprocesualny czy post-postproceualny, a bardziej na zagadnieniach, które wyłoniła współczesność, takich jak sprawczość, neomaterializm, dziedzictwo archeologiczne, uteoretycznienie badań terenowych, postkolonializm, feminizm itp. Nie zmienia to faktu, że postmodernistyczna krytyka w archeologii pobudziła ją do nowej refleksji, szukania rozwiązań, ale na pewno już w świecie „po Latourze”, który opisuje pradzieje w kategoriach „redystrybucji”, ponownego złożenia tego, co społeczne, ale w kategoriach „kłącza”, „uwikłania”, w rozrastających się „,sieciach” między artefaktami, krajobrazami i ludźmi. Choć niezaprzeczalnym problemem jest świat w stałym stawaniu się i kardynalne pytanie, czy można w nim cokolwiek uchwycić w ramach studium przypadku? W takim razie, na czym polega ta zmiana? Myślę, że nie na wielkiej „rewolucji” i w związku z tym odwołam się do Fredrica Fahlandera (2012), że „śmierć” postmodernizmu jest przesadzona i on sam ma się dobrze, a pewne postulaty post-postmodernizmu można traktować jak dyskusję międzypokoleniową. Moim zdaniem jest to trafna diagnoza także dla archeologii, a obecna sytuacja stanowi efekt dyskusji postmodernistycznej danego pokolenia, nawet jeśli dokładnie nie potrafimy zdefiniować jej skutków. By uniknąć pewnych pułapek, archeolodzy zajęli się zagadnieniami teoretycznymi, historią myśli archeologicznej, zarządzaniem dziedzictwem, współczesną edukacją muzealną, a więc tym, co ma wagę również $\mathrm{w}$ praktyce archeologicznej. W takim razie różnice między metodologią prof. Jana Żaka a obecnym kształtem teorii i metodologii powinniśmy traktować jako naturalny proces związany z wchodzeniem na arenę kolejnego pokolenia czy kolejnych pokoleń, zajmujących się teorią i metodologią archeologii na miarę własnych czasów.

\section{BIBLIOGRAFIA}

Düring, B. S., Marciniak, A.

2005 Households and communities in the central Anatolian Neolithic. Archaeological Dialogues, 12(2), 165-187.

Fahlander, F.

2012 Are we they yet? Archaeology and the postmodern in the new millennium. Current Swedish Archaeology, 20, 109-129.

Foucault, M.

1977 Archeologia wiedzy. Warszawa: Państwowy Instytut Wydawniczy.

Jankhun, H.

1983 Wprowadzenie do archeologii osadnictwa. Poznań: Poznańskie Towarzystwo Przyjaciół Nauk.

Kolenda, J., Rączkowski, W.

2018 Anatomia pustki: o archeologicznym rekonesansie lotniczym w północno-wschodniej części Dolnego Śląska. Przegląd Archeologiczny, 66, 283-318. 
Mamzer, $\mathrm{H}$.

2000 Kulturowe konteksty ,paradygmatów” w archeologii. W: M. Kobusiewicz, S. Kurnatowski (red.), Archeologia i prahistoria polska w ostatnim pótwieczu (s. 537-550). Poznań: PTPN

2020 „Mowa obrończa” metodologii archeologów Uniwersytetu im. Adama Mickiewicza w Poznaniu. Folia Praehistorica Posnaniensia, 25, 110-148.

Marciniak, A.

1996 Archeologia i jej źródla. Materialy faunistyczne w praktyce badawczej archeologii. Poznan - Warszawa: PWN.

Marciniak, A.

2005 Placing Animals in the Neolithic: Social Zooarchaeology of Prehistoric Farming Communities. London: UCL Press.

2006 From animals and food in space to bones in context. Social zooarchaeology of the Neolithic farming communities. W: D. Papaconsantinou (red.), Deconstructing Context. A Critical Approach to Archaeological Practice (s. 34-49). Oxford: Oxbow.

2012a Teoria w archeologii. W: S. Tabaczyński, A. Marciniak, D. Cyngot, A. Zalewska (red.), Przeszłość społeczna. Próba konceptualizacji (s. 84-116). Poznań: Wydawnictwo Poznańskie.

2012b Paradygmaty badawcze w archeologii. W: S. Tabaczyński, A. Marciniak, D. Cyngot, A. Zalewska (red.), Przeszłość społeczna. Próba konceptualizacji (s. 29-83). Poznań: Wydawnictwo Poznańskie.

2012c Przedstawianie i narratywizm w archeologii. W: S. Tabaczyński, A. Marciniak, D. Cyngot, A. Zalewska (red.), Przeszłość spoteczna. Próba konceptualizacji (s. 162-177). Poznań: Wydawnictwo Poznańskie.

2013 Byki, uczty i kozioł ofiarny. René Girard i jego uczniowie w Çatalhöyük. Rocznik Antropologii Historii, 3(2), 169-184.

2015a Mainstream and minority archaeologies. The case of the beginnings of the Polish bioarchaeology. W: K. Kristiansen, L. Šmejda, J. Turek (red.), Paradigm Found. Archaeological Theory - Present, Past and Future. Essays in Honour of Evžen Neustupný (s. 137-146). Oxford: Oxbow.

2015b Śmierć, grób i zmarły w tworzeniu i przekształcaniu systemów religijnych w neolicie Bliskiego Wschodu. Przypadek osady w Çatalhöyük. W: W. Dzieduszycki i J. Wrzesiński (red.), Studia Lednickie, Spotkanie 17. Cmentarzyska - relacje spoleczne i międzykulturowe (s. 89-100). Poznań: Stowarzyszenie Naukowe Archeologów Polskich Oddział w Poznaniu.

2020 Od śmierci do życia. Archeologia wobec ograniczeń antropologii fizycznej. W: J. Goszczyńska, H. Machajewski, A. Skrzeczyńska, M. Błażejewska (red.), Archeologia miejsc funeralnych $w$ Wielkopolsce (s. 11-21). Poznań: Wielkopolski Wojewódzki Konserwator Zabytków, Stowarzyszenie Naukowe Archeologów Polskich Oddział Wielkopolski.

Marciniak, A., Asouti, E., Doherty C., Henton, E.

2015 The nature of household in the upper levels at Çatalhöyük. Smaller, More Dispersed, and More Independent Acquisition, Production, and Consumption Unit. W: I. Hodder, A. Marciniak (red.), Assembling Çatalhöyük (s. 151-165). Leeds: Maney Publishing.

Marciniak, A., Minta-Tworzowska, D., Pawleta, M. (red.)

2011 Wspótczesne oblicza przeszłości. Poznań: Wydawnictwo Poznańskie.

Marciniak, A., Pawleta, M., Kajda, K. (red.)

2018 Dziedzictwo we wspótczesnym świecie. Kultura, natura, człowiek. Kraków: Universitas. Minta-Tworzowska, D.

1991 Pamięci Profesora doktora Jana Żaka (1923-1990), współtwórcy współczesnej prahistorii polskiej. Archeologia Polski, 36(1-2), 321-333.

1994 Klasyfikacja w archeologii jako sposób wyrażania wyników badań, hipotez i teorii archeologicznych. Poznań: Wydawnictwo Naukowe UAM. 
2000a Contemporary Debates in Archaeology: the exemple of classification- Part 1. Nova Revista de Historia da Arte e Arqueologia, 3, 218-224.

2000b Kwestia przełomu metodologicznego w prahistorii i w archeologii polskiej. W: M. Kobusiewicz, S. Kurnatowski (red.), Archeologia i prahistoria polska w ostatnim pótwieczu (s. 527-535). Poznań: Wydawnictwo PTPN.

2000c Postmodernizm, myśl poststrukturalistyczna a archeologia (zarys problematyki). W: A. Buko, P. Urbańczyk (red.), Archeologia $w$ teorii i praktyce. Warszawa: Komitet Nauk Pra- i Protohistorycznych PAN, IAiE PAN.

2000d Świat archeologii w świetle źródeł archeologicznych. Acta Historica et Museologica Universitatis Silesianae Opaviensis, 5, 49-59.

2001a Życie i działalność Profesora dr. hab. Jana Żaka. W: D. Minta-Tworzowska, W. Rączkowski (red.), Archeologia - Paradygmat - Pamięć (s. 19-35). Poznań: Wydawnictwo Poznańskie.

2001b Profesora Jana Żaka poszukiwanie paradygmatu. W: D. Minta-Tworzowska, W. Rączkowski (red.), Archeologia - Paradygmat-Pamięć (s. 109-122). Poznań: Wydawnictwo Poznańskie.

2002 Between a community of inspiration and the separateness of archaeological traditions. W: P. F. Biehl, A. Gramsch, A. Marciniak (red.), Archäologien Europas. Geschichte, Methoden, und Theorien Archaeologies of Europe: History, Methods and Theories (s. 53-64). Münster: Waxmann.

2011 Człowiek i rzecz w perspektywie archeologicznej, czyli rzecz w perspektywie antropocentrycznej. W: A. Marciniak, D. Minta-Tworzowska, M. Pawleta (red.), Współczesne oblicza przeszłości (s. 39-61). Poznań: Wydawnictwo Poznańskie.

2013 Pamięć, miejsca pamięci jako budujące tożsamość w ujęciu archeologii. Przegląd Archeologiczny, 61, 1-15.

2019 Jan Żak. W: Z. Pilarczyk (red.), Uniwersytet Poznański (1919-2019). Luminarze nauki Uniwersytetu w Poznaniu w latach 1945-2019 (s. 862-867). Poznań: Wydawnictwo Naukowe Uniwersytetu im. Adama Mickiewicza w Poznaniu.

2001c Archeologia-Paradygmat-Pamięć. W dziesiąta rocznicę śmierci Profesora Jana Żaka. W: D. Minta-Tworzowska, W. Rączkowski (red.), Archeologia-Paradygmat-Pamięć (s. 7-15). Poznań: Wydawnictwo Poznańskie.

2021 Are we where we wanted to be? Modernist tendencies versus the postmodern reality of archaeology. Some remarks on the methodology of archaeologists at Adam Mickiewicz University in Poznań. W: D. Żurkiewicz (red.), Treasures of Time. Research of the Faculty of Archaeology of Adam Mickiewicz in Poznań (s. 452-473). Poznań: Wydawnictwo Wydziału Archeologii UAM.

Minta-Tworzowska, D., Pawleta, M.

2013 Teoria i metodologia archeologii na Uniwersytecie im. Adama Mickiewicza w Poznaniu. Folia Praehistorica Posnaniensia, 18, 221-237.

Minta-Tworzowska, D., Rączkowski, W.

1996 Theoretical Traditions in Contemporary Polish Archaeology. World Archaeological Bulletin, 8, 196-209.

2007 Standardy teoretyczne we współczesnej polskiej archeologii. W: J. Lech (red.), Pót wieku $z$ dziejów archeologii polskiej (1939-1989) (s. 219-247). Warszawa: PWN.

Minta-Tworzowska, D., Rączkowski, W. (red.)

2001a Archeologia-paradygmat-pamięć. Poznań: Wydawnictwo Poznańskie.

Minta-Tworzowska, D., Rączkowski, W.

2001b Archeologia-Paradygmat-Pamięć. W dziesiąta rocznicę śmieci Profesora Jana Żaka. W: D. Minta-Tworzowska, W. Rączkowski (red.), Archeologia-paradygmat-- pamięć (s. 7-15). Poznań: Wydawnictwo Poznańskie. 
Pałubicka, A., Tabaczyński, S.

1986 Społeczeństwo i kultura jako przedmiot badań archeologicznych. W: G. Donato, W. Hensel, S. Tabaczyński (red.), Teoria i praktyka badań archeologicznych. Przesłanki metodologiczne, t. 1, (s. 57-148). Warszawa - Wrocław - Kraków - Gdańsk: Zakład Narodowy im. Ossolińskich.

Pawleta, M.

2015 Kręgi kamienne na Pomorzu w koncepcji „miejsc pamięci”. W: B. Gediga, A. Grossman, W. Piotrowski (red.), Miejsca pamięci. Pradzieje, średniowiecze i współczesność (s. 385414), Biskupin - Wrocław: Muzeum Archeologiczne w Biskupinie, IAiE PAN.

2016 Przeszłość we wspótczesności. Studium metodologiczne archeologicznie kreowanej przeszlości w przestrzeni spolecznej. Poznań: Wydawnictwo Naukowe UAM.

2017 Theatrum archaeologicum: staging the past via archaeological fêtes and historical reenactment. Sprawozdania Archeologiczne, 69, 33-53.

2019 Archaeotourism spaces in present-day Poland: Thoughts on reconstruction and reenactments. W: D. C. Comer, A. Willems (red.), Feasible Management of Archaeological Heritage Sites Open to Tourism (s. 115-127). Cham: Springer.

2020 Archeologia odpowiedzialna społecznie. Działania z zakresu public i community archaeology w Polsce. Folia Praehistorica Posnaniensia, 25, 169-190.

Rączkowski, W.

2002 Archeologia lotnicza - metoda wobec teorii. Poznań: Wydawnictwo Naukowe UAM.

2011 Teoria, empiria i praktyka. Archeologiczne dyskursy w sieci zależności i opozycji. Acta Archaeologica Resoviensia, 4, 23-34.

2017a Praktyki badawcze archeologów: kilka refleksji o wykorzystaniu metod nieinwazyjnych. W: A. Różański (red.), Gemma Gemmarum (s. 323-342), Poznań: PTPN, WH UAM.

2017b Zdjęcia lotnicze badań wykopaliskowych w Biskupinie - w stronę efektywnej interpretacji. Sprawozdania Biskupińskie, 5, 9-16.

2017c Historyczne przestrzenie miasta we współczesnym kontekście - z dystansu. W: W. Rączkowski, J. Sroka (red.), Historia i kultura ziemi sławieńskiej (s. 261-286), t. 12. Sławno: Fundacja Dziedzictwo.

2018 O rzece i grzęzawisku. W: H. Machajewski (red.), Archeologia dawnego osadnictwa Wielkopolski (s. 11-30). Poznań: WKZ, SNAP.

2020a Power and/or penury of Visualizations: Some Thoughts on Remote Sensing Data and Products in Archaeology. Remote Sensing, 12, 1-23.

2020b Historische Ladschaften aus der Perspective der Fernerkundung. W: O. Kuhne, T. Strobekl, R. Traba, M. Wiatr (red.), Kulturlandschaften in Deutchland und Polen (s. 133-152). Göttingen: V\&R unipress.

Tabaczyński, S.

1985 Zjawisko nieciągłości jako przedmiot analizy archeologicznej. Folia Praehistorica Posnaniensia, 1, 7-22.

Tabaczyński, S., Marciniak, A., Cyngot, D., Zalewska, A. (red.)

2012 Przeszłość spoteczna. Próba konceptualizacji. Poznań: Wydawnictwo Poznańskie.

Topolski, J.

1984 Metodologia historii. Warszawa: PWN.

Żak, J.

1959 Najstarsze ostrogi zachodniosłowiańskie. Wczesnośredniowieczne ostrogi o zaczepach haczykowato zagiętych do wnętrza. Warszawa - Wrocław: Zakład Narodowy im. Ossolińskich.

1962 Studia nad kontaktami handlowymi społeczeństw zachodniostowiańskich ze skandynawskimi od VI do VIII wieku. Wrocław - Warszawa - Kraków: Zakład Narodowy im. Ossolińskich. 
1963 „Importy” skandynawskie na ziemiach zachodniosłowiańskich od IX do XI wieku. Poznań: Wydawnictwo Naukowe UAM.

1969 Wczesnofeudalna Skandynawia. Wrocław - Warszawa - Kraków: Zakład Narodowy im. Ossolińskich

1974-1975 Słowianie i Germanie w prahistorii polskiej i niemieckiej. W: J. Krasucki, G. Labuda, A. Walczak (red.), Stosunki polsko-niemieckie w historiografii, cz.1. (s. 21-149). Poznań: Instytut Zachodni.

1975a Ziemie polskie w starożytności i we wczesnym średniowieczu. W: J. Topolski (red.), Dzieje Polski (s. 14-76). Warszawa: PWN.

1975b Próba przedmiotowego modelu kultury społeczeństw młodszego i schyłkowego paleolitu (strefy śródziemnomorskiej). Fontes Archaeologici Posnanienses, 25, 28-59.

1975c Uwagi teoretyczne o refleksji prahistorycznej. Archeologia Polski, 20(2), 259-273.

1977 O studiach osadniczych. Archeologia Polski, 22(2), 421-424.

1980 Kwestia kontynuacji/dyskontynuacji w V/VI wieku (materiaty do dyskusji). Kraków: Muzeum Archeologiczne.

1985a Uwagi metodologiczne nad problemem osadnictwa. Studia Metodologiczne, 24, 77-87.

1985b O kontynuacji/dyskontynuacji społecznej i kulturowej na ziemiach nadodrzańskich i nadwiślańskich w V-V/VI wieku n.e. Folia Praehistorica Posnaniensia, 1, 85-105.

1988 Wprowadzenie. W: J. Piontek (red.), Szkice z antropologii ogólnej (s. 9-12). Poznań: Wydawnictwo Naukowe UAM.

Żak, J., Maćkowiak-Kotkowska, L.

1988 Studia nad uzbrojeniem środkowoeuropejskim $w$ VI-X wieku. Zachodniobaltyjskie i stowiańskie ostrogi o zaczepach haczykowato zagiętych do wnętrza. Poznań: Wydawnictwo Naukowe UAM.

Żuk, L.

2015 Rzeczywistości pamięci społeczności pradziejowych. W: B. Gediga, A. Grossman, W. Piotrowski (red.), Miejsca pamięci. Pradzieje, średniowiecze i wspótczesność (s. 79-110). Biskupin - Wrocław: Muzeum Archeologiczne w Biskupinie, IAiE PAN.

2019 Pamięć o krajobrazie jako kategoria analizy archeologicznej. Poznań [niepublikowana praca doktorska].

\title{
METHODOLOGY OF ARCHEOLOGY / PREHISTORY OF PROFESSOR JAN ŻAK (1923- 1990) AFTER 30 YEARS. BETWEEN MODERNIST DESIGN AND POSTMODERNIST REALITY
}

\author{
S u m m a ry
}

This article aims to show the importance of Professor Jan Żak's scientific works 30 years after his death. He died prematurely at the age of 67 on January 4, 1990. His scientific output and views on archeology were shaped by the times in which he lived. His life covered the Second World Warat the beginning of 1945 he crossed the Apennines and joined the 1st Brigade of the 3rd Carpathian Rifle Division, taking part in all its subsequent hostilities. After the end of hostilities, he was sent to the cadet school in Matera, Italy, but in August 1946 he went with the entire school to England, to Yorkshire. However, he did not choose to live outside Poland, where, after returning, he functioned in the realities of the People's Republic of Poland. He died shortly after the anti-communist breakthrough. The main goal is to recall and try to look anew at the methodology of archeology that the Professor created and promoted. 
It should be remembered that he was awarded the highest state decorations, such as the Officer's Cross of the Order of Polonia Restituta (in 1987). It is also impossible to ignore his important functions, including he was a long-time director of the Institute of Prehistory, which he founded in 1982 at the Adam Mickiewicz University in Poznan. He belonged to many scientific councils, especially museums, including archaeological ones, he was a correspondent member of the German Archaeological Institute and many others. He sat on the editorial boards of many scientific journals.

He was sensitive to other people's matters. The numerous students gathered around him admired him for his fighting spirit, visible especially in his long illness, but above all for his great knowledge, especially about the European Middle Ages, which did not narrow his horizons. He conducted all discussions passionately, because he was a great erudite, he thought quickly, synthesized quickly and also moved to practical examples. He created the practical so-called a school in Bniń, related to research on an early medieval stronghold, and a Poznań archaeological school with a clear focus on the methodology of archaeological research. He was a teacher who allowed his students to think and work independently. He was also a man of ideas, always putting the good of others ahead of his own, and the Institute of Prehistory was for him his superior good, which he identified with.

His research and work focused on 1) the early Middle Ages, not only in Poland, but also in the Scandinavian countries, 2) the issue of "theoreticalising" of settlement studies (Żak, 1977; 1985a, p. 3) methodology of archaeological research. In particular, the methodology was originally and passionately developed by him, and he focused on the issue of continuation / discontinuation of social existence in the context of the economy (Żak, 1985b), and in relation to prehistoric times, he thought about the reflection of the prehistoric man, trying to build the object model of contemporary societies (Żak, 1975b).

It was also important for me to try to answer the question of what is the methodology of archeology at AMU after the 30 years that have passed since the Professor's death. What has undoubtedly changed over the last 30 years is that the research fields that methodologists and theorists of archeology at the University of Poznań deal with have expanded. Therefore, my goal was also to present the contemporary methodology and theory of archeology practiced by Jan Żak's students and subsequent generations. I have dealt with this issue in a confrontation that clashes modernist aspirations with postmodern reality in terms of attitudes, principles and values that have a huge impact on archeology and archaeologists. Students grew up on the basis of modernist aspirations, dreams that archeology would be among the highly developed sciences. However, postmodernity has shown that the world of archeology is heading in a fundamentally different direction. The achievements of archaeologists from AMU, which were noticeable quite early, can be divided into two different methodological approaches: humanistic and natural science. Despite the continuation of some general assumptions (reflection on the theory of archeology, research procedure, on the archaeological source, paradigms in archeology, etc.), it cannot be denied that the attempt to oust modernism by postmodernism and then post-postmodernism could not remain without impact on the present the shape of the theory and methodology of archeology, also in Poznan. In order to avoid certain pitfalls, archaeologists dealt with theoretical issues, the history of archaeological thought, heritage management, contemporary museum education, and therefore with what is also important in archaeological practice. Therefore, the differences between the methodology of prof. Jan Żak, and the current shape of the theory and methodology should be treated as a natural process related to entering the arena of the next generation or subsequent generations, dealing with the theory and methodology of archeology for their own times. 
